\title{
Trauma e Infância : Considerações sobre a Vivência de Situações Potencialmente Traumáticas
}

\author{
Dione de Medeiros Lula Zavaroni ${ }^{1}$ \\ Terezinha Camargo Viana \\ Universidade de Brasilia
}

\begin{abstract}
RESUMO - A partir da teoria freudiana, o artigo propõe uma discussão em torno do lugar ocupado pelo acontecimento na constituição do trauma. O principal ponto de interesse consiste em pensar as conseqüências da vivência, ainda na infância, de acontecimentos considerados traumáticos. É proposto o termo situação potencialmente traumática para nomear o acontecimento presente na constituição do trauma, em oposição ao termo situação traumática. Do ponto de vista metapsicológico, o trabalho propõe o uso dos termos desamparo primário e desamparo secundário, em paralelo aos termos freudianos de narcisismo primário e narcisismo secundário, para pensar o lugar do desamparo na constituição do trauma.
\end{abstract}

Palavras-chave: trauma, desamparo, narcisismo,infância, Freud

\section{Trauma and Childhood: Considerations about the Potentially Traumatic Situation}

\begin{abstract}
In the context of Freudian theory, this article intends to discuss the place of experienced events in the constitution of trauma. The main focus of this debate consists in thinking about the consequences of experiencing events considered traumatic during childhood. The term potentially traumatic situation is suggested as a form of designating this event implicated in the constitution of trauma, in opposition to the term traumatic situation. In a metapsychological perspective, this paper proposes the use of the terms primary helplessness and secondary helplessness, parallel to the terms primary narcissism and secondary narcissism, to think about the place of helplessness in the constitution of trauma.
\end{abstract}

Keywords:trauma, helplessness, narcissism,c hildhood, Freud

O trauma sempre ocupou um lugar de destaque na metapsicologia freudiana. Gradativamente, as dimensões dinâmica, tópica e econômica do psiquismo foram sendo incorporadas às discussões sobre o trauma. Em um movimento de compreensão a posteriori, Freud elaborou um complexo corpo teórico sobre as conseqüências do encontro do sujeito com situações traumáticas no período da infância. A construção freudiana aconteceu, sobretudo, a partir da fala de pacientes adultos no desvendamento de seus sintomas e no encontro, em análise, com as lembranças, fantasias e acontecimentos referentes à infância. Em um encontro a posteriori, o adulto se depara comfragmentos de lembranças de cenas e situações vivenciadas atribuindo-lhes significados e realizando um trabalho de reconstrução, onde os efeitos dessas vivências são compreendidos no depois do seu acontecer.

Mas, se por um lado, a psicanálise considera o trauma de maneira mais ampla e complexa, sendo entendido como um processo inerente à constituição psíquica, por outro, também o entende como algo que impede o fluxo pulsional e que paralisa o acontecer psíquico em alguma de suas dimensões. É neste segundo sentido que pretendemos problematizá-lo, a partir de uma discussão metapsicológica em torno das ressonâncias psíquicas geradas pelo encontro da criança com situações potencialmente traumáticas.

A expressão situação potencialmente traumática é usada com a intenção de ressaltar apotencialidade traumática das

1 Endereço para correspondência: Campus Universitário Darcy Ribeiro, ICC Ala Sul, Instituto de Psicologia, Universidade de Brasília, Asa Norte, Brasília, DF, Brasil. CEP: 70.910-900.E-mail: zavaroni@unb. br situações adversas, em oposição à compreensão da existência de uma relação linear entre a experiência vivida e o trauma. O propósito é sinalizar uma oposição à noção de trauma pensada a partir de um a priori traumático. Na psicanálise, a definição do que consideramos como situação potencialmente traumática nos coloca diante de questões metapsicológicas fundamentais. É importante demarcar que tratamos de uma construção teórica que ao mesmo tempo em que advém das questões trazidas pela clínica, viabiliza um fazer clínico pautado em uma compreensão do funcionamento psíquico que, por sua vez, só adquire sentido dentro do trabalho clínico sustentado pela psicanálise.

De modo genérico, definimos como potencialmente traumática uma situação composta de circunstâncias impactantes, geradoras de pesar, que coloca a criança frente a perdas importantes e que exige ou desencadeia (re)arranjos vivenciais significativos. Tais como acontece nas situações que envolvem a perda inesperada de alguém significativo, a agressão física ou psíquica, os acidentes familiares e pessoais com consequências graves, dentre tantos outros. No entanto, situações que não contemplam tanta visibilidade também podem constituir-se como situações potencialmente traumáticas, como por exemplo, a perda de um pequeno brinquedo. Mas nosso interesse volta-se principalmente para aquelas situações que, a revelia do sujeito, possuem um forte atributo traumático que lhe é conferido pelo próprio sujeito, pela família ou pelo seu contexto cultural. A ideia de situação potencialmente traumática contempla a compreensão freudiana sobre o trauma e problematiza a eficácia traumática do acontecimento vivido. 
As situações potencialmente traumáticas impõem ao sujeito um trabalho psíquico intenso, demandando a disponibilidade de recursos internos capazes de reorganizar os elementos integrantes do $\mathrm{Eu}$ e a relação do $\mathrm{Eu}$ com o mundo externo. Neste sentido, podemos nos perguntar se na primeira infância, tempo por excelência da constituição psíquica, tais situações teriam maiores chances de se tornarem traumáticas, considerando que as defesas psíquicas para seu enfrentamento ainda não se encontram plenamente constituídas deixando o sujeito a mercê das demandas pulsionais e das circunstâncias ambientais?

\section{Primeiras construções sobre o trauma na obra freudiana}

Nos escritos psicanalíticos, desde Freud, o conceito de trauma tem se apresentado de maneiras diversas. Segundo Doin (2005, p.02), "o conceito de trauma passou a incluir agressões de vários tipos, acabando por significar qualquer fator patogênico, qualquer acontecimento grave, mais ou menos circunscrito, único ou repetitivo, ou mesmo qualquer situação crônica danosa". Diante da amplitude assumida pela idéia de trauma dentro da psicanálise, consideramos relevante valer-se da obra freudiana e alçar alguns elementos delimitadores da noção de trauma.

No início deste artigo, apontamos que o manejo do conceito de trauma possibilita duas compreensões: o trauma entendido quase como sinônimo de situação traumática e o trauma como processo psíquico. $\mathrm{O}$ trauma como um processo psíquico refere-se, principalmente, ao aspecto inerente ao próprio acontecer psíquico que inevitavelmente, confrontará o sujeito com situações de intensa angústia. A constituição psíquica está permeada e se faz, ela mesma, através destas vivências emocionais mobilizadoras de angústia que serão, sucessivamente, revividas. A compreensão do trauma que remete à vivência de uma situação traumática se relaciona, mais especificamente, à experiência de determinadas situações. Nossa proposição é de que estas duas vertentes do trauma estão estreitamente relacionadas, embora não sejam completamente coincidentes, não podem ser pensadas em oposição, mas em sobreposição. Esse é um ponto de tensão que será retomado em formatos diversos ao longo da obra freudiana e que atribuirá às discussões sobre o trauma complexidade e extensão significativas.

Laplanche e Pontalis (1988) apresentam uma síntese de vários aspectos abordados por Freud ao longo de sua obra. Esses autores apresentam a seguinte definição de trauma:

"Acontecimento da vida do indivíduo que se define pela sua intensidade e pela incapacidade em que se acha o indivíduo de lhe responder de forma adequada, pelo transtorno e pelos efeitos patogênicos duradouros que provoca na organização psíquica. Em termos econômicos, o traumatismo caracterizase por um afluxo de excitações que é excessivo, relativamente à tolerância do indivíduo e a sua capacidade de dominar e de elaborar psiquicamente estas excitações" (p. 678, grifos nossos).

A partir do conceito acima, identificamos alguns elementos fundamentais. Em primeiro lugar, o trauma refere-se sempre a algo que diz respeito à intensidade de um acontecimento.
Na obra freudiana, percebemos que esse acontecimento é inicialmente considerado como um acontecimento externo e passa, gradativamente, a constituir-se, sobretudo, mesmo que não completamente, como um evento interno. Além disso, Freud passa de uma posição mais próxima ao entendimento de que o trauma é gerado principalmente pela vivência de um acontecimento com o qual o sujeito se depara (Freud, 1950/1980f) à compreensão do trauma mais interligado a noção do desamparo (Freud, 1926/1980d).

Além do aspecto econômico, a síntese apresentada na definição de Laplanche e Pontalis (1988) ressalta a importância de um encontro do evento intenso com uma susceptibilidade (Empfanglichkeit) do sujeito. Esse encontro terá efeitos patogênicos em consequência da pré-condição psíquica e da impossibilidade de o sujeito elaborar o excesso de excitação. De qualquer modo, consideramos que desde o princípio, existe uma especificidade na construção freudiana que diz respeito à necessidade de pensarmos o trauma para além do fato em si. Ou seja, a vivência de situações adversas não estabelece a priori a inscrição do trauma no psiquismo. Se, por outro lado, a psicanálise reconhece a existência de situações que imprimem um excesso pulsional com o qual o sujeito tem que se haver, por outro, será apenas no registro da singularidade do sujeito exposto a tais condições, que a experiência vivida irá constituir-se psiquicamente.

Outra característica da noção do trauma proposta por Freud (1950/1980f) refere-se à consideração de que o trauma não é, necessariamente, desencadeado por um grande acontecimento. Muitas vezes, o elemento desencadeante do trauma são situações corriqueiras vividas no cotidiano. Desse modo, no ensaio escrito em 1895 , Freud (1950/1980f) já oferece um lugar de fundamental importância aos componentes psíquicos que se agregam à vivência do acontecimento. Consideramos que para Freud não se trata de por em oposição as experiências vividas e os elementos pulsionais na constituição do trauma, mas de pensar em um entrelaçamento imprescindível e inflexível entre os acontecimentos e os traços pulsionais constituintes do psiquismo.

Essa compreensão será realçada na Carta 52 (Freud, 1950/1980c), de 06 de dezembro de 1896. Nessa Carta a Fliess, Freud (1950/1980c) utiliza a metáfora da escrita para falar do funcionamento psíquico e, a partir da idéia do traço mnêmico, discute o processo de transcrição das inscrições deixadas no psiquismo pelas experiências infantis. Percebemos, já nesse momento, uma alusão não especificamente ao que foi vivido, mas às marcas deixadas pelas experiências de prazer e desprazer que a criança vivenciou. Vemos, portanto, esboçada a importante consideração de que o aparelho psíquico não está constituído desde as origens e que seu processo de constituição depende das experiências atravessadas ao longo da vida. No Projeto para uma psicologia científica, Freud (1950/1980f) considera que essas experiências serão orientadas pela condição de desamparo à qual o recém-nascido está submetido e às conseqüentes relações que estabelecerá, desde muito cedo, com os outros que dele se ocupam (Zavaroni, Viana, \& Celes, 2007).

Outro elemento apresentado por Freud (1950/1980f) na construção teórica em torno do trauma refere-se à 
compreensão de uma cena primeira que se atualiza em uma situação traumática atual. Freud (1950/1980f) discute essa ideia em torno do Caso Emma, onde a cena mais remota e inconsciente mantém uma conexão determinante com outra cena mais recente e considera que isso acontece em decorrência do desenvolvimento da sexualidade na adolescência. Posteriormente, com a descoberta da sexualidade infantil, Freud (1905/1980g) reconhece que a cena mais recente trará de volta o conteúdo sexual da cena infantil que permaneceu recalcado. É, nesse sentido, que Freud (1950/1980f) irá falar da ação adiada do trauma. Ou seja, a cena só torna-se traumatizante posteriormente. Aidéia de uma ação a posteriori se transmutará, mas permanecerá na teoria freudiana até o final de sua obra e consiste na compreensão de que algo ouvido ou vivido poderá não ter um efeito no momento de seu acontecimento, mas, por uma ação do recalque, ter sua ação adiada e comparecer apenas posteriormente na formação dos sintomas. Embora possa, também, ser compreendida como uma ação das vivências atuais na interpretação de algo passado, a noção da ação a posteriori é importante na discussão sobre o trauma porque a mesma será a sustentação da noção do trauma em dois tempos (Hanns, 1996).

Segundo a teoria do trauma que se estrutura em dois tempos, a cena traumática se forma na conjunção da cena primeira, recalcada, com a cena atual que evoca aquela. A cena atual reconduz o sujeito a um tempo anterior e o trauma está na obscuridade dessa relação. Portanto, para a psicanálise, uma cena traumática é na verdade um evento psíquico miscigenado e não isolado na história do sujeito. No entanto, esses eventos não dizem respeito, necessariamente, a fatos, mas podem referir-se ao traço mnêmico recalcado que permanece em seu efeito no psiquismo. É uma noção complexa no sentido em que não restringe a compreensão do trauma ao acontecimento, mas também não a desvincula do mesmo, pois todo trauma está associado a um acontecimento. Porém, é fundamental compreendermos o que Freud considerava quando apontava para a existência de um acontecimento no trauma.

A Carta 69 (Freud, 1950/1980c) é um marco importante no desenvolvimento dessa discussão. É nesse trabalho que Freud declara, "não acredito mais na minha neurótica", e assim expressa seu dilema diante da constatação clínica de que a sedução infantil (o acontecimento) nem sempre está presente na constituição do trauma, como ele próprio havia, anteriormente, afirmado. Não se trata do abandono da teoria traumática que inscreve na etiologia das neuroses a presença de um acontecimento, mais precisamente, de um acontecimento de caráter sexual. Teoricamente, a virada consiste no fato de que Freud passa a considerar a fantasia na constituição das cenas traumáticas rememoradas. No tratamento psicanalítico de suas pacientes, Freud deduz que a referência à vivência de uma sedução na infância não se tratava necessariamente de uma experiência vivida, mas de algo fantasiado. Desse modo, a partir desse momento a realidade material da cena do trauma passa a ser questionada. Portanto, o que Freud (1950/1980c) problematiza não é a existência de um acontecimento desencadeador do trauma ou a origem traumática da neurose, mas a natureza do trauma, deslocando-o da realidade material para a realidade psíquica (Zavaroni et al., 2007).

As discussões realizadas no contexto acima apresentado apontam para os tênues limites entre fantasia e realidade. Os conceitos de realidade psíquica e realidade material são introduzidos por Freud para possibilitar que pensemos o interno e o externo em termos não espaciais (do dentro e do fora), mas como realidades que possuem o mesmo valor e que irão se apresentar em uma interdependência que caracteriza o movimento constante dos investimentos pulsionais. Por outro lado, embora o limite entre realidade psíquica e realidade material seja algo de difícil demarcação, esta última pode ser compreendida como as situações presentes no lócus onde o sujeito se insere. Ou seja, são as situações que circundam o sujeito, desde as características da mãe ou seu substituto, até as condições de vida e as heranças culturais nas quais o sujeito está imerso. Porém, a partir da psicanálise freudiana, não encontramos sustentação para falar de uma realidade que se situa completamente fora do sujeito. O que temos na verdade é um entrelaçamento impossível de ser desfeito entre o interno e o externo. A relação mãe-bebê talvez seja um bom modelo da interseção dos diversos elementos constituintes desse entrelaçamento, ou seja, situa-se como algo que se encontra entre realidade material e realidade psíquica. Ao mesmo tempo em que existe uma mãe que cuida e um bebê que é cuidado, esses cuidados são vias de constituição psíquica do bebê e da constituição da imagem desse bebê no psiquismo materno.

Além dos aspectos anteriores, é importante colocar em realce a interseção entre trauma e desamparo já apontada por Freud (1950/1980f, 1926/1980d) e que propomos problematizar a partir da clínica psicanalítica com crianças. Para Freud (1950/1980f,1926/1980d), o desamparo não é algo restrito às condições de vida ou algo a ser superado na vida adulta, mas, antes, uma condição que acompanha de modo perene o acontecer psíquico. Porém, no caso da criança, a necessidade de atendimento às condições básicas de proteção e de sobrevivência a colocam em estreita relação de dependência ao outro e a vivência de situações potencialmente traumáticas pode constituir-se em um fator mobilizador de experiências emocionais impressas no psiquismo e impregnados da angústia precoce vivida nos momentos iniciais de vida. Na criança a relação entre trauma e desamparo pode ser particularmente potencializada pela condição de que, na infância,a condição de dependência ao outro ainda encontra respaldo na realidade do corpo infantil que não pode prescindir do outro para sua sobrevivência.

\section{Articulações entre o trauma, o desamparoe o estranho em Freud}

Como já afirmamos, na compreensão freudiana sobre o trauma sempre existe um excesso pulsional que se estende para além das possibilidades que o sujeito dispõe de colocar no circuito associativo de idéias, um quantum de energia que não cessa de exigir descarga. A idéia de um acúmulo de tensão não descarregada discutida por Freud (1920/1980a) em, Além do Princípio do Prazer, será retomada no texto Inibição, Sintoma e Ansiedade (Freud, 1926/1980d). Nesse trabalho, 
Freud acrescenta elementos importantes sobre a compreensão do trauma, que consiste, basicamente, no entendimento de que o acúmulo de excitação, que poderá ser de origem externa ou interna, psíquica ou física, remete o sujeito ao estado de desamparo, considerado por Freud (1950/1980f) o protótipo da situação traumática.

A vivência primordial do desamparo é desencadeada pela impossibilidade do bebê em realizar a ação específica indispensável à satisfação de suas necessidades. Estritamente dependente dos adultos que o circunda, o bebê está na dependência do acolhimento de suas demandas e da realização, por parte de seus cuidadores, da ação específica necessária à satisfação de suas necessidades e ao escoamento da tensão desencadeada pelas mesmas.Quando este cuidado falha ou falta, podemos pensar que a criança poderá vivenciar situações de intensa angustia pelo desamparo avassalador que a invade.

Mas mesmo na vida adulta o desamparo nunca é completamente superado, pois o desamparo é um estado inerente à condição humana. Embora considerando que o adulto não abandona sua condição de desamparo, essa condição na criança ainda é estreitamente relacionada à sobrevivência física e psíquica. Mas a vivência real de desamparo acarretaria um estado de vulnerabilidade psíquica ainda maior? Como nos aponta a clínica psicanalítica com crianças, não temos como afirmar tal condição por antecedência. O destino das situações vividas dependerá, certamente, do aparato psíquico da criança e daqueles que cuidam dela, das situações de vida com as quais, sucessivamente, irá se deparar e, particularmente, da possibilidade de estar em um processo de análise ainda na infância.

As situações potencialmente traumáticas se situam como um dos possíveis elementos que remetem o sujeito ao estado de desamparo. No entanto, as situações potencialmente traumáticas, os estímulos físicos ou os conteúdos psíquicos não alcançam, isoladamente, o estatuto de um trauma. Este está na conjunção entre fatores pertencentes a tais contextos e que se colocam uns sobre os outros. Tornam-se traumáticos ou porque recolocam a criança diante do traço psíquico recalcado referido ao desamparo experimentado nos primeiros momentos da constituição psíquica, ou por serem carregados de uma intensidade que exige da criança um trabalho psíquico que se coloca para além de suas possibilidades. Assim, as situações potencialmente traumáticas não são o trauma, mas um componente que em uma leitura à posteriori identificamos como um dos elementos presentes no processo que o desencadeia. $\mathrm{O}$ trauma também não se consiste nos sintomas que o sujeito pode apresentar após a vivência de tais situações, como por exemplo, as fobias, o pânico, a recusa alimentar, etc. O trauma consiste em um processo psíquico que pode se revelar através de tais manifestações sintomáticas.

Outra noção importante nas discussões sobre o trauma apresenta-se nas elaborações freudianas sobre o estranho. $\mathrm{O}$ encontro com situações potencialmente traumáticas exige do sujeito a operacionalização de uma via no trânsito pulsional que possibilite o escoamento da angústia gerada pelo encontro com o estranho (Unheimlich) (Freud, 1919/1980e), que pode ser interpretada como a (re)vivência de sensações primordiais de desamparo, que foram originalmente recalcadas, e que, provavelmente, sobrevêm no psiquismo infantil em forma de um estranhamento inominável.

Freud (1919/1980e) afirma,

"entre os exemplos de coisas assustadoras, deve haver uma categoria em que o elemento que amedronta pode mostrarse ser algo reprimido que retorna. Essa categoria de coisas assustadoras constituiria então o estranho...Esse estranho não é nada novo ou alheio, porém algo que é familiar e há muito estabelecido na mente, e que somente se alienou desta através do processo da repressão" (p. 300-301).

Segundo Hanns (1996), a concepção do estranho em Freud (1919/1980e) remete a duas compreensões. Por um lado, é o que pertence ao externo, ao outro, ao desconhecido. É o estranho como aquilo que se refere ao novo, ao não reconhecido, ao não representável. Mas o estranho é também considerado no sentido do estranho familiar que remete o sujeito a algo submetido ao recalque, e por isso mesmo (re) atualizador do desprazer. É algo que desperta a angústia primordial vivenciada nas condições precoces da relação do bebê com sua mãe. Todos estes aspectos relacionados ao estranho estarão intrinsecamente relacionados no engendramento do trauma. Assim, o estranhamento com o qual o sujeito se depara no trauma pode ser tanto algo posto antes mesmo do encontro com o acontecimento que o desencadeou e que foi, por assim dizer, reatualizado, como também pode ser algo desconhecido porque vindo do outro, do externo invade o sujeito. Deste modo, entendemos que a presença de algo que é da ordem do desconhecido assume uma posição particularmente relevante nas situações potencialmente traumáticas. Tanto porque remete ao que está recalcado como pelo que de inesperado se apresenta ao sujeito.

\section{Desamparo e Narcisismo}

Freud (1914/2004a) afirma que

"o narcisismo, que se constitui ao chamar de novo para si os investimentos anteriormente depositados nos objetos, pode ser concebido como um narcisismo secundário, superposto a outro, primário. Todavia, as inúmeras e variadas influências sofridas pelo narcisismo secundário obscurecem nossa visão do processo" (p. 98).

Essa definição do narcisismo comporta um aspecto que consideramos fundamental, tanto na compreensão dos processos psíquicos presentes na constituição do narcisismo primário e do narcisismo secundário, como também do que propomos chamar desamparo primário e desamparo secundário.

Em primeiro lugar, ela estabelece uma diferença sem, contudo, estabelecer uma ruptura entre os dois conceitos. Além disso, ressalta uma característica da construção metapsicológica freudiana, que consiste na sobreposição de conceitos e, mais que isso, na sobreposição de modos do acontecer psíquico. Ou seja, o narcisismo secundário não substitui o narcisismo primário fundando no sujeito uma nova forma de funcionamento psíquico, mas o sobrepõe guardando,com este, semelhanças, ao mesmo tempo em que estabelece diferenças. 
É, nesse sentido, que pensamos os conceitos aqui propostos de desamparo primário e desamparo secundário. $\mathrm{O}$ desamparo primário coincide com a compreensão freudiana de desamparo que aparece no Projeto para uma psicologia científica e refere-se à condição física e psíquica do recémnascido que impõe e determina sua relação com os outros. Segundo Freud (1950/1980f), o desamparo está na base das relações que o recém-nascido estabelece com aqueles que o cuida. Mais do que uma condição física, entendemos que Freud considera o desamparo como um estado psíquico mobilizador de uma profunda angústia que exige um movimento pulsional com vistas a aplacá-la.

O desamparo secundário seria o momento posterior em que esta condição inicial volta a apresentar-se ao sujeito, fazendo-o reviver sensações e sentimentos arcaicos. Essa condição do desamparo secundário não é "nenhuma condição nova, mas, como sabemos, a amplificação e explicitação de um estado que já existia antes", como afirmou Freud (1914/2004a, vol. 14, p. 98) em relação ao narcisismo secundário.

Ainda no estabelecimento de um paralelo entre a proposta de Freud para pensar o narcisismo e o que aqui propomos para pensar o desamparo, ressaltamos que ao mesmo tempo em que na psicose aparece de modo amplificado aspectos do narcisismo próprios à constituição psíquica, pensamos que o trauma psíquico coloca em destaque o desamparo com o qual todo sujeito está às voltas. O desamparo que o sujeito vivencia diante de situações potencialmente traumáticas não é algo novo que se instala no momento em que tais situações se apresentam. É um estado que ressurge no psiquismo e que reconduz o sujeito a uma vivência primordial, já esquecida, embora não completamente sobrepujada.

A vivência do desamparo primário está relacionada tanto com o aparato psíquico e físico que o bebê dispõe para defrontar-se com a angústia precoce,quanto com o modo como aqueles com quem o bebê estabelece os primeiros laços podem responder a sua condição de fragilidade e dependência. Como afirma Freud (1950/1980f), o desconforto gerado pela fome exige ao bebê uma descarga motora que desencadeia o choro. $\mathrm{O}$ adulto que cuida do bebê responde a esse apelo que no mesmo instante já abandona a condição de simples descarga e passa a ser um signo de comunicação. O choro passa, assim, a ser um chamado, que, gradualmente, passa a adquirir, tanto para o bebê como para o outro que o atende, um significado próprio. Entre o chamado e a presença do outro, o bebê vivencia a sua condição inevitável de dependência e abandono.

Winnicott (1965/1983) teoriza em torno desse momento da constituição psíquica e nos oferece um elemento importante para pensá-lo. Segundo esse autor, entre a necessidade e a sua satisfação, o bebê desenvolve a capacidade de alucinar a presença do objeto. Traumático e constitutivo, o hiato entre a necessidade e o objeto que lhe atende é fundamental no desenvolvimento de outra capacidade: a capacidade de estar só, também estudada por Winnicott (1965/1983). Assim, não será, necessariamente, o pronto atendimento das necessidades do bebê, mas todo o contexto em que esta necessidade é atendida, que determinará o traçado pulsional que se constitui precocemente no psiquismo. É nesse contexto, que se encontra a demanda do bebê, o hiato, o objeto, o outro.
Para Winnicott (1987/2006), este momento inicial, que aqui chamaremos de momento de acolhimento do desamparo, é dotado de tamanha singularidade que esse autor chega a considerar dentre seus elementos até mesmo o modo como o bebê é sustentado no colo. Em um momento posterior da vida, todo esse aparato psíquico constituído em um momento tão precoce, estará presente demarcando o modo como o sujeito (criança ou adulto) poderá manejar seu encontro com as diversas situações de vida.

Os elementos arcaicos estão intrinsecamente relacionados constituindo uma teia psíquica onde aparece um constante movimento caleidoscópico. É essa constante possibilidade de novas configurações que permitirá à criança desvencilhar-se das amarras traumáticas. Nesse movimento, não podemos desconsiderar o lugar que o outro, o adulto que cuida e que oferece sentidos, ocupa no desenrolar desse processo. Às voltas com seu sofrimento, a criança convoca o outro como suporte àquilo que, para ela, escapa à significação. Mas essa demanda ao outro não passa apenas pelos cuidados voltados ao corpo ou pelo amparo psíquico. Ela se lança exatamente entre o físico e o psíquico, na interseção realçada por Freud (1915/2004b) no conceito de Trieb. É uma demanda que se pronuncia nos meandros pulsionais.

Se, por um lado, é importante que os cuidadores possam minimizar para a criança o impacto das situações invasivas e agressoras às quais a mesma está submetida, por outro, é fundamental que possam oferecer-lhe sustentação para que elabore o que vivencia. Trata-se, assim, de encontrar no repertório psíquico referências primordiais que se encontram no registro das primeiras sensações junto ao corpo materno.

Como afirma Endo (2003), "após o trauma, este é o material bruto com o qual o psiquismo terá de trabalhar, na forja do prosseguimento da própria história onde tudo parece ter sido interrompido" (p. 120). Porém, mais do que recontar a história da vivência da situação potencialmente traumática, a criança poderá buscar sentidos para fragmentos articulados em sua própria fala e na fala de seus cuidadores. Se, em analise, trata-se de uma reconstrução (Freud, 1937/1980c), no sentido de que é a retomada em um segundo momento, de algo que se passou em um momento primeiro.

\section{Assituações potencialmente traumáticas na clínica com crianças: recortes do caso Marina}

$\mathrm{O}$ atendimento de Marina, nome fictício dado a uma menina de cinco anos de idade, é particularmente instigante no trabalho de construção das questões aqui propostas. Quando bebê, Marina vivenciou situações de negligência, fome e frio. Aos dois anos e meio, saiu do convívio familiar e viveu por alguns meses em uma instituição de menores. Aos 3 anos, passou por um processo de adoção. Segundo relato de sua atual família, quando morava com sua família de origem, várias vezes, Marina foi atendida por vizinhos que ouviam seu choro incessante. Retirada do abrigo pela família que a adotou e com a qual mora até hoje, Marina recebeu todos os cuidados necessários para sua recuperação, pois estava desnutrida, com peso e estatura abaixo de sua faixa etária. As situações adversas vividas por Marina são os principais fatores que sustentam o pedido de atendimento feito por 
sua mãe. Outras queixas aparecem de modo secundário, tais como, dificuldades de aprendizagem, dificuldades de relacionamento e agressividade.

Desde sua chegada para o atendimento, a mãe adotiva mostrava uma particular preocupação com o fato de Marina ter vivido situações tão adversas no começo de sua vida, a despeito dos cuidados atuais que recebia e da recuperação que apresentava. Para a analista de Marina, a questão que advinha era como as experiências dos primeiros anos de vida desta criança compareciam em sua organização psíquica e como vivências tão adversas para um bebê, como a negligência, a fome e o frio faziam parte do repertório psíquico de Marina. O transcorrer do seu atendimento foi, de algum modo, possibilitando a construção de algumas hipóteses.

As situações vividas por Marina comportam uma potencialidade traumática dificilmente questionável. No entanto, o ponto em discussão consiste exatamente em questionar esse potencial traumático. Exposta a situações de desamparo emblemáticas nos primeiros anos de vida, Marina nos traz a questão da possibilidade de superação diante da falta de acolhimento de suas demandas primárias de cuidados e da repercussão disso em sua constituição psíquica. Como célula e fonte primária da constituição psíquica, o corpo do bebê se coloca como mediador das sensações vividas no convívio humano. Através dos cuidados maternos, o bebê passa a reconhecer uma realidade corporificada inicialmente através do adulto que lhe alimenta, acolhe, agasalha e ama. $\mathrm{O}$ acolhimento pelo outro das demandas iniciais viabiliza o processo de constituição posto em cena deste os primeiros instantes de vida. Na falta dos cuidados maternos, o bebê é colocado a mercê de suas demandas pulsionais. $\mathrm{O}$ desconforto não atendido lança o bebê na busca de superação que só encontrará saída pela via da fantasia e da alucinação. $\mathrm{O}$ seio imaginado diante da fome e não substituído pelo seio real prende o bebê à construção fantasmática de sua onipotência associada às sensações incessantes do desconforto corpóreo da fome. Sem a presença do outro que lhe atende, o bebê permanece sem o referencial da realidade que o coloca diante de sua incompletude humana permanecendo em sua ilusão de que nele mesmo se completa. $\mathrm{O}$ outro que não atende denuncia de forma cruel a sua inexistência, podendo lançar o bebê em um desamparo que presentifica e reafirma o desamparo próprio a sua condição humana de constituir-se em relação.

Em momentos ainda muito precoces da vida de Marina, a realidade convoca as vivências de desamparo e esses conteúdos se reapresentam trazendo suas marcas. Não são apenas vivências primárias próprias ao desamparo apontado por Freud, mas também vivências já postas em um segundo momento, embora que também muito precoce. É exatamente essa revivência que aqui nomeamos como desamparo secundário. Trazendo as marcas do desamparo primário, o desamparo secundário o reatualiza. Entre o físico e o psíquico, entre realidade e fantasia, o desamparo secundário relança Marina na busca de defesas possíveis ao seu enfrentamento. Embora marcados pela presença de eventos da realidade externa e do corpo, tanto o desamparo primário como o desamparo secundário são processos inconscientes.

No caso Marina, o choro que chama os vizinhos nos apontaria para outra possibilidade diante do abandono?
Poderíamos pensar em um enfrentamento da angústia do desamparo que se confirmava na realidade? De certa forma, podemos pensar que Marina foi salva por seu choro que atravessa a impossibilidade de seus pais biológicos e ecoa nos ouvidos de outros que lhe ouvem e lhe socorrem. Não sabemos o quanto Marina esteve exposta ao hiato entre a descarga e o chamado, entre o chamado e a chegada do outro, mas certamente foi um tempo que ainda lhe possibilitou uma confrontação com um outro real estruturante.

A denúncia da vivência das situações adversas no início de sua vida chega ao atendimento através do discurso de sua mãe adotiva. Em análise, Marina, gradativamente, constitui sua própria demanda. Ela trazia através de seus sintomas sinais de uma organização psíquica que ficou marcada pelas vivências precoces da negligência e do abandono em seus cuidados primários. Sobretudo a partir do que apresenta em sessão, Marina revelava um esforço gigantesco de significação e integração ou mesmo de apropriação dos arranjos psíquicos que engendrou diante de tais vivências. As sessões circulavam, sobretudo, em torno de aspectos relacionados ao abandono, aos objetos bons e maus e aos recursos disponíveis para enfrentamento do desamparo, exemplificados nos recortes que trazemos a seguir.

Nas primeiras sessões, Marina mostrava-se muito agitada, dispersa e angustiada. As sessões iniciais foram muito conturbadas. Marina pegava vários brinquedos sem deter-se em nenhum deles e sua produção gráfica era basicamente rabiscos e borrões de tinta. No momento de encerrar a sessão, Marina nunca aceitava. Corria pela sala, dizia que não ia sair. A analista falava do medo que ela sentia em partir e deixála para trás, e reafirmava que estariam de volta na sessão seguinte, e que ela, a analista, estaria esperando por Marina.

As dificuldades em torno da saída repetem-se por várias sessões. Em uma sessão em que a saída parecia particularmente difícil (Marina corria, pulava e ria de modo ansioso), a analista oferece uma folha de papel em branco para que Marina a leve para casa. De repente, diante desta oferta, Marina pára, aceita a folha e a leva consigo. Por várias sessões, Marina passou a sair mediante a oferta da folha de papel e nunca traz essa folha de volta ou fala sobre ela nas sessões seguintes. A folha em branco, que parece ter assumido a função mediadora que possibilitou a separação de Marina da analista, nos remete às elaborações winnicottianas sobre o objeto transicional que, entre o interno e o externo, torna possível à criança o seu distanciamento do outro (Winnicott, 1958/1988).

Depois de alguns meses de atendimento, sempre com muitas dificuldades em separar-se da analista no final das sessões, Marina começa a fazer um jogo na entrada da sessão, que passa a ser compreendido pela analista como uma versão do jogo do fort-dà (Freud, 1920/1980a). No corredor que dá acesso à sala de atendimento, Marina ordena que a analistacaminhe enquanto ela se esconde. A analista, pensando na importância do desaparecimento e do sucessivo ressurgimento de Marina, aceita o jogo proposto: olha para trás e finge que não a ver escondida atrás de uma pilastra e pergunta: "Cadê a Marina?" Ela reaparece e a analista diz: "Ah, você está ai". Marina se diverte com o jogo, ri bastante e, várias vezes, pede que o repita. Ela vai assim até a porta da sala e finalmente entra. Nesse jogo, a analista pressupõe 
que Marina encenava o seu próprio desaparecimento e o da analista. Paralelamente a este jogo, Marina vai parando de resistir à separação da saída.

Após as sessões iniciais, Marina começa a propor brincadeiras com temas específicos. Em uma das sessões, ela pega os utensílios de cozinha e diz que está preparando comida para seus filhos. Marina encena as funções maternas de modo carinhoso e acolhedor. Pega os bonecos delicadamente nos braços, fala carinhosamente, parece encantada com "seus bebês". No meio de uma dessas brincadeiras, ela insere um pequeno boneco e diz que é mais um filho. Em determinado momento, coloca o boneco no forno de um fogãozinho de brinquedo e diz: "É aí que você vai dormir". E, desde então, passa a fazer parte de seu brincar um bebê que oscila entre bom e mal, e em contrapartida uma mãe boa e má. Marina intercala cuidados e agressões ao bebê. Agressões que às vezes vem da mãe e outras de uma babá que introduz nas brincadeiras. Em muitos momentos, existem duas mulheres em torno dos bebês, geralmente uma mãe cuidadosa e uma babá que não cuida bem dos bebês.

De um brincar desorganizado, ansioso e tumultuado, Marina foi gradativamente passando a um brincar mais tranquilo e a uma apropriação de suas questões. Após alguns meses de atendimento, outras brincadeiras passam a ser muito freqüentes em suas sessões. Ela propõe e encena situações onde aparecem uma mãe e uma criança ameaçadas por lobos, monstros e raptores em noites escuras. Nestas brincadeiras, sempre existia uma criança em perigo e um lobo ou um ladrão que pretendia raptá-la. Essa criança era sempre vivida por ela. À analista, ela atribuía o lugar da mãe que lutava contra o lobo, ou do pai que vinha defender a mãe e a filha do raptor. A analista pensava que lobo, raptor, defensor, mãe e pai eram significantes que figuravam na composição dos objetos iniciais introjetados por Marina. Parecia que, através da inserção destes temas em seu brincar, Marina atualizava as fantasias que revestiam as experiências vividas precocemente em sua vida em torno da saída da casa de seus pais biológicos, da ida para a instituição de menores e do seu acolhimento em uma nova família.

Em outras sessões, ela apagava as luzes da sala, dizia que era noite e que iriam todos dormir. Nestes momentos, frequentemente, Marina sentava ao lado da analista, deitava a cabeça em seu colo e pedia que cantasse canções de ninar. Em outros momentos, Marina atribuía à analista o lugar de uma mãe má, repressora, que ela xingava veementemente, e a quem dizia que ia embora. Marina atualizava na relação transferencial a vivência ambivalente de seu lugar de filha. O medo e o desejo de ser ao mesmo tempo levada e deixada, a figura ambígua de um protetor/ameaçador que aparecia constantemente, as fantasias em relação à escuridão que gerava medos e a impossibilitava de dormir sozinha foram, frequentemente, trazidos durante muitas sessões. A analista entedia que suportar as idas e vindas de Marina no jogo entre o amor e o ódio pareciam fundamentais no prosseguimento de sua análise.

Em alguns momentos, Marina esteve muito colada às produções e às falas da analista. Ela chega mesmo a deslizar de suas falas e produções e "apropriar-se" do que a analista falava ou fazia em sessão. Isto faz pensar que Marina estava trilhando o próprio caminho da constituição psíquica, projetando na analista suas fantasias e apropriandose daquilo que a mesma lhe oferecia em forma de discurso, desenhos e produções. A relação transferencial pautada em idas e vindas em relação ao amor e à agressão que dirigia à analista parece ter possibilitado com que Marina vivenciasse as suas questões tendo conseguido, por fim, estabelecer uma produtiva aliança terapêutica.

A grande capacidade de brincar revelada por Marina no transcorrer das sessões nos faz pensar em um bebê que, para além das adversidades, pode se sustentar em laços afetivos significativos que, certamente, ampararam sua constituição psíquica precoce. Com uma grande possibilidade de brincar e encenar, Marina reconstruiu suas relações primordiais e trouxe ao atendimento as questões referentes às vivências adversas de seus primeiros anos de vida, revelando uma significativa capacidade de enfrentamento da angústia e de superação das carências. Desde o seu choro que chama os vizinhos que de algum modo lhe socorre, até seu engajamento no processo de análise, Marina revela um significativo potencial psíquico de superação. Nesta via, pensamos que, para além das precariedades de alimentação e conforto, e das rupturas vivenciadas, Marina teve, de algum modo, elementos significativos oriundos da relação dela com seus diversos cuidadores e em que se sustentou nos momentos precoces de sua constituição psíquica.

Brincando e encenando ser mãe, ser bebê ou filha, Marina reeditava, provavelmente, as situações potencialmente traumáticas vivenciadas no início de sua vida e as fantasias articuladas em torno de tais vivências. Ao mesmo tempo, seu brincar revela uma tentativa de integração dos diversos elementos que constituíam essas vivências, o que aparece, sobretudo, através da inserção dos diversos personagens que encarnam o bem e o mal e que a possibilitam reencenar a ambivalência vivida nos diversos episódios de sua vida. Talvez, uma reedição da ambivalência própria à constituição psíquica, mas também, a atualização em sessão da ambivalência vivida em suas relações, que ela precisava dar conta e que aparecia constantemente em seu brincar.

O Caso Marina nos faz compreender que os recursos psíquicos de uma criança são fundamentais na elaboração e significação das situações potencialmente traumáticas. Além disso, este caso nos sinaliza que é necessário que existam recursos ambientais que possibilitem à criança cuidados que possam sustentá-la em seu desamparo. Por fim, consideramos que a psicanálise ainda na infância de Marina teve, certamente, um lugar relevante em seu processo de constituição psíquica possibilitando que processos precoces pudessem ser reorganizados. Neste sentido, podemos pensar que as situações adversas de sua infância puderam permanecer em seu psiquismo como situações potencialmente traumáticas que, embora comportassem uma tendência a produzir um trauma impeditivo se seu desenvolvimento puderam ser ressignificadas e inseridas em seu repertório psíquico. Embora não possamos afirmar que tais situações nunca assumirão o potencial traumático que comportam, podemos afirmar que sustentá-las como potencialmente traumáticas pode ter sido fundamental no destino das mudanças viabilizadoras da organização psíquica de Marina através de sua análise. 


\section{Referências}

Doin, C. (2005). O ego busca seu trauma: paradoxos da traumatofilia. Texto apresentado no $44^{\circ}$ Congresso Internacional de Psicanálise da IPA, Rio de Janeiro. Retrievedfromhttp:// webcache.googleusercontent.com/search?q=cache:Gw73 5eFHAbIJ:febrapsi.org.br/publicacoes/artigos/doin_ipa. $\mathrm{doc}+\& \mathrm{~cd}=1 \& \mathrm{hl}=\mathrm{pt}-\mathrm{BR} \& \mathrm{ct}=\mathrm{clnk} \& \mathrm{gl}=\mathrm{br}$

Endo, P. (2003). Acidente, trauma e catástrofe na clínica psicanalítica. In R. A. Pacheco, Filho et al. (Eds.), Novas contribuições metapsicológicas à clínica psicanalítica. (pp. 115-124). São Paulo: Cabral Editora e Livraria Universitária.

Freud, S. (1980a). Além do princípio do prazer. In Edição standard brasileira das obras psicológicas completas de S. Freud. (J. Salomão, Trans..) (Vol. 18, pp. 17-90). Rio de Janeiro: Imago. (Trabalho original publicado em 1920)

Freud, S. (1980c). Extratos dos documentos dirigidos a Fliess. In Edição standard brasileira das obras psicológicas completas de S. Freud. (J. Salomão, Trans..) (Vol. 1, pp. 243-380). Rio de Janeiro: Imago. (Trabalho original publicado em 1950)

Freud, S. (1980d). Inibições, sintomas e ansiedade. In Edição standard brasileira das obras psicológicas completas de $S$. Freud. (J. Salomão, Trans..) (Vol. 20, pp. 107-211). Rio de Janeiro: Imago. (Trabalho original publicado em 1926)

Freud, S. (1980e). O Estranho. In Edição standard brasileira das obras psicológicas completas de S. Freud. (J. Salomão, Trans..) (Vol. 17, pp. 273-318). Rio de Janeiro: Imago. (Trabalho original publicado em 1919)

Freud, S. (1980f). Projeto para uma psicologia cientifica. In Edição standard brasileira das obras psicológicas completas de $S$. Freud. (J. Salomão, Trans..) (Vol. 1, pp. 381-520). Rio de Janeiro: Imago. (Trabalho original publicado em 1950)
Freud, S. (1980g). Três ensaios sobre a teoria da sexualidade. In Edição standard brasileira das obras psicológicas completas de S. Freud. (J. Salomão, Trans..) (Vol. 7, pp. 121-252). Rio de Janeiro: Imago. (Obra original publicada em 1905).

Freud, S. (2004a). À Guisa de Introdução ao Narcisismo. In Obras psicológicas de Sigmund Freud. Escritos sobre a Psicologia do Inconsciente. (L. A. Hanns, Trans..) (Vol. 1, pp. 95-132). Rio de Janeiro: Imago. (Trabalho original publicado em 1914)

Freud, S. (2004b). Pulsões e destinos da pulsão. In Obras psicológicas de Sigmund Freud. Escritos sobre a Psicologia do Inconsciente. (L. A. Hanns, Trans.) (Vol. 1, pp. 133-174). Rio de Janeiro: Imago. (Trabalho original publicado em 1915)

Hanns, L. A. (1996). Dicionário comentado do alemão de Freud. Rio de Janeiro: Imago.

Laplanche, J. \& Pontalis, J.-B. (1988). Vocabulário de Psicanálise. (10 a ed.) (P. Tramen, Trans.). São Paulo: Martins Fontes.

Winnicott, D. W. (1983). O ambiente e os processos de maturação. (I. C. S. Ortiz, Trans..). Porto Alegre: Artes Médicas. (Trabalho original publicado em 1965)

Winnicott, D. W. (1988). Textos selecionados: da pediatria à psicanálise. ( $4^{\mathrm{a}}$. Ed.) (J. Russo, Trans..). Rio de Janeiro: Francisco Alves. (Trabalho original publicado em 1958)

Winnicott, D.W. (2006). Os bebês e suas mães.( $3^{\mathrm{a}}$ ed.). (J. L. Camargo, Trans..). São Paulo: Martins Fontes. (Trabalho original publicado em 1987)

Zavaroni, D. M. L., Viana, T. D. C. \& Celes, L. A. M. (2007). A constituição do infantil na obra de Freud. Estudos de Psicologia (Natal), 12, 65-70.
Recebido em 10.12.2013

Primeira decisão editorial em 15.02.2014

Versão final em 15.02.2014

Aceito em 20.02.2014 